\title{
Hubungan Antara Pengguna Aplikasi dan Motivasi Instrinsik dengan Perilaku Hidup Sehat (Berdasarkan Tingkat Usia)
}

\section{Relationship between Application Use and Intrinsic Motivation with Healthy Behavior (Based on Age Level)}

\author{
Riyanti, Nurlan Kusmaedi, \& Amung Ma'mun \\ Universitas Pendidikan Indonesia, Bandung, Jawa Barat, Indonesia \\ riyanti@upi.edu, nurlankusmaedi@upi.edu, \& amung@upi.edu
}

Naskah diterima tanggal 17/07/2019, direvisi akhir tanggal 09/10/2019, disetujui tanggal 23/12/2019

\begin{abstract}
Abstrak
Peneltian ini bertujuan untuk mengetahui hubungan antara pengguna aplikasi, dan motivasi intrinsik dengan perilaku hidup sehat pada komunitas lari berdasarkan gender dan tingkat usia. Metode yang digunakan adalah korelasional (deskriptif). Teknik pengumpulan data yang digunakan dalam penelitian ini adalah kuesioner. Tehnik pengambilan sampel menggunakan simple random sampling. Jumlah sampel 143 orang kualifikasi tingkat usia (remaja 13 - 18 dan dewasa 18 - 40) dari 580 populasi pada 3 komunitas lari yang ada di Kota Bandung diantaranya: Indorunners Bandung, Fakerunners Bandung dan RIOT Bandung (running is our therapy). Hasil penelitian ini menunjukkah bahwa: (1) terdapat hubungan antara pengguna aplikasi dengan perilaku hidup sehat (2), terdapat hubungan antara motivasi intrinsik dengan perilaku hidup sehat (3), terdapat hubungan antara pengguna aplikasi dan motivasi ekstrinsik dengan perilaku hidup sehat.
\end{abstract}

Kata kunci: Pengguna aplikasi, motivasi instrinsik, perilaku hidup sehat

\section{Abstract}

This study aims to determine the relationship between application users, and intrinsic motivation with healthy living behavior in running communities based on gender and age level. The method used is correlational (descriptive). The data collection technique used in this study was a questionnaire. The sampling technique uses simple random sampling. The total sample is 143 qualifying people of age (adolescents 13-18 and adults 18-40) of 580 populations in 3 running communities in Bandung, including Indorunners Bandung, Fakerunners Bandung, and RIOT Bandung (running is our therapy). The results of this study indicate that: (1) There is a relationship between application users and healthy behavior; (2) There is a relationship between intrinsic motivation and healthy behavior; (3) There is a relationship between application users and extrinsic motivation with healthy behavior.

Keywords: Application users, intrinsic motivation, healthy behavior.

\section{PENDAHULUAN}

Transformasi digitalisasi pada bidang teknologi di era globalisasi ini, membawa manusia pada suatu keadaan dimna mereka mampudenganmudahmemperolehinformasi. Hal ini didukung melalui perkembangan ilmu pengetahuan dan teknologi sehingga mampu membentuk suatu keadaan atau peradaban baru pada kondisi manusia saat ini yang sangat kental akan dunia digital. Teknologi diciptakan oleh manusia dengan tujuan mempermudah segala aktivitas manusia dalam memenuhi kebutuhannya. Atau dapat juga dikatan sebagai alat penunjang 
bagi manusia, sehingga mereka mampu beradaptasi dan bertahan hidup layak dan nyaman. Tekonologi modern telah menjadi penentu utama status sosial ekonomi yang menyebar secara cepat pada seluruh generasi (Bhattacharyya, 2015).

Dalam beberapa tahun terakhir teknologi modern telah mengalami ekspansi besar yang mengarah ke penggunaannya secara luas oleh orang-orang dari semua generasi (Simuforosa, 2013). Teknologi informasi dan berkomunikasi menjadi pokok perhatian utama dalam perkembangan media saat ini. Hal ini dibuktikan banyaknya orangorang yang tertarik untuk menggunakan perangkat teknologi canggih untuk memudahkan kinerjanya, salah satunya adalah gadget. Upadhyay et al., (2014) elektronik Gadget sangat populer dan orangorang sangat tertarik untuk menggunakan elektronik gadget. Gadget adalah bagian dari teknologi informasi dan komunikasi (TIK) yang banyak digunakan.

Teknologi gadget dengan berbagai macam jenisnya mulai dari smartphonel mobile phone, tablet, laptop dan sumber layanan (Internet) menjadi generasi dari berbagai kalangan usia. Subrahmanyam et al., (2000) menyatakan bahwa banyak orangorang yang menghabiskan rata-rata waktu di berbagai gadget seperti smartphonel mobile phone, radio, TV, game, Xbox, iPod dan stereo system. Gadget merupakan alat atau media komunikasi berteknologi canggih. Gadget dalam pengertian umum dianggap sebagai suatu perangkat elektronik yang memiliki fungsi khusus pada setiap perangkatnya. Selain itu, Gadget adalah salah satu inovasi yang dihasilkan oleh manusia untuk mempermudah pekerjaan atau untuk kepentingan setiap hari karena dengan adanya gadget akan mudah mendapatkan berbagai macam informasi yang dibutuhkan dengan sekali tekan (Rahmat, 2017).

Menurut kominfo (2015) Indonesia menjadi negara dengan penggunaan aktif smartphone terbesar keempat di dunia setelah Cina, India, dan Amerika. Berdasarkan data Hootsuite yang dikutif Bisnis.com (2018) menunjukkan rata - rata orang di
Indonesia memanfaatkan smartphone jumlah penggunaan pada Januari 2018 menembus 132,7 juta pengguna dengan tingkat penetrasi mencapai 50\%. Dari data tersebut, tercata pengguna aktif media sosial sebesar sebesar 130 juta. Hootsuite merupakan sebuah situs layanan manajemen konten yang menyediakan layanan media daring yang juga terhubung dengan berbagai situs jejaring sosial lainnya, seperti: facebook, twitter, linkedIn, foursquare, myspace, dan wordpress. Populasi penggunaan perangkat mobile angkanya lebih tinggi lagi yang mencapai 1779 juta pengguna, dengan tingkat penetrasi mencapai $67 \%$. Terbukti bahwa di Indonesia memiliki banyak peminat dalam penggunaan smartphone. Dampak lain dari peggunaan smartphone selain sikap sedentari yang ditimbulkan, smartphone menyebabkan kurangnya siswa melakukan perilaku hidup sehat dalam kehidupan sehari-hari (yaitu aktivitas fisik).

Ketidakaktifan fisik berkontribusi terhadap sekitar 3,2 juta kematian setiap tahun dan merupakan faktor risiko utama keempat untuk kematian dini (WHO, 2018; WHO 2009). Terlepas dari kenyataan bahwa banyak orang tidak mematuhi rekomendasi aktivitas fisik (WHO, 2018; WHO, 2010). Ketidakaktifan fisik adalah faktor risiko utama obesitas, diabetes mellitus, dan penyebab utama kematian dini akibat kardiovaskular penyakit (Smart \& Marwick, 2004; Taylor et al., 2004), kanker (Lee, 2003) dan penyakit kronis lainnya. Ketidakaktifan fisik merupakan masalah kesehatan masyarakat yang terus berkembang.

Akan tetapi, smartphone dapat dimanfaatkan dengan baik yaitu pemanfaatannya lebih kearah positif. Seperti dapat mengunduh aplikasi yang mempromosikan aktivitas fisik. Fanning et al., (2012); Dallinga et al., (2015); \& Vos et al., (2015) mengungkapkan bahwa aplikasi smartphone memiliki beberapa keunggulan dalam potensinya untuk menjadi alat yang kuat untuk mempromosikan dan merangsang aktivitas fisik. Antara lain, mereka memiliki jangkauan yang luas dan mudah diakses, pengguna dapat membawanya dan 
mengakses data di mana saja dan kapan saja, mereka dapat memberikan peluang umpan balik, data sistem penentuan posisi global dapat digunakan, dll. Meskipun smartphone dapat dianggap sebagai platform yang menarik untuk pelatihan (Kranz et al., 2013), sebagian besar aplikasi terkait kebugaran dan kesehatan (hanya) memberikan umpan balik tentang kinerja, sementara panduan khusus terbatas (Middelweerd et al., 2014). Adapun penelitian yang berkaitan dengan aplikasi oleh Janssen et al., (2017) bahwa aplikasi yang paling populer di antara pelari adalah Runkeeper, diikuti oleh Runtastic dan Nike Running.

Di sisi lain, smartphone adalah barang olahraga non-spesifik, tetapi ketika menggunakan aplikasi yang terkait dengan olahraga, ia menghasilkan produk yang digunakan untuk umum (bukan spesifik) menjadi barang olahraga (Janssen et al., 2017). Sebuah studi di antara peserta dalam sebuah acara lari rekreasi, menunjukkan bahwa pengguna aplikasi smartphone terkait berlari (i) Cenderung lebih aktif secara fisik dan merasa lebih sehat, dan (ii) Memiliki niat yang lebih tinggi untuk mempertahankan perilaku berlari mereka (Dallinga et al., 2015). Penggunaan aplikasi seluler (aplikasi) alat yang ampuh untuk mendorong aktivitas fisik dan gaya hidup sehat.

Tindakan atau perilaku manusia selalu ditentukan oleh dua faktor, yaitu faktor yang datang dari luar dan faktor yang datang dari dalam dirinya sendiri. Teixeira et al., (2012) Bahwa motivasi adalah faktor penting dalam mendukung olahraga berkelanjutan, yang pada gilirannya dikaitkan dengan hasil kesehatan yang penting. Orang yang sudah terbiasa melakukan olahraga cendrung akan merasa tertekan apabila tidak melakukan olahraga dalam sehari.

Zaman sekarang, banyak sekali orang yang lebih banyak melakukan aktivitas seperti berkumpul bersama teman sebayanya, atau berdiam diri bersama teman-teman di suatu tempat seperti café, cozy place dan sebagainya. Bahkan banyak dari mereka yang lebih memilih untuk menghabiskan waktu mereka untuk bermain video game, mereka pun menjadi tergantung pada kecanggihan teknologi seperti smartphone. Mereka lebih tertarik untuk melakukan hal tersebut karena menurut mereka hal tersebut merupakan hal yang menyenangkan. Sedikit jumlah dari mereka yang memilih beraktivitas fisik di luar ruangan, tentunya dengan keinginan dan motivasi yang berbeda. Keberagaman motivasi yang dimiliki menjadi alasan utama untuk mereka memilih aktivitas fisik di luar ruangan ini. Sedikit jumlah dari mereka yang memilih beraktivitas fisik di luar ruangan, tentunya dengan keinginan dan motivasi yang berbeda.

Keberagaman motivasi yang dimiliki menjadi alasan utama untuk mereka memilih aktivitas fisik di luar ruangan ini. Penggunaan smartphone pada zaman sekarang ini memiliki potensi sebagai media untuk program perubahan perilaku hidup sehat, tetapi belum ada studi yang motif dari mereka menggunakan aplikasi yang terdapat pada smarthpone mereka. Ketertarikan penulis dalam meneliti hubungan antara pengguna aplikasi olahraga dan motivasi intrinsik terhadap perilaku hidup sehat. Penulis ingin mengetahui respon motivasi dari para pengguna Running Apps mengkaji dan yang mendorong mereka untuk untuk berpartisipasi melakukan aktifitas fisik untuk menuju perilaku hidup sehat pada komunitas lari berdasarkan kualifikasi tingkat usia remaja dan dewasa.

\section{METODE PENELITIAN}

Metode penelitian yang digunakan adalah deskriptif korelasional correlastinal research. Populasi yang digunakan dalam penelitian ini adalah komunitas lari yang telah mengikuti aktivitas fisik dikomunitasnya masing masing berjumlah 580 orang. Teknik sampling yang digunakan dalam penelitian ini adalah menggunakan simple random sampling yaitu dengan memberikan peluang yang sama kepada anggota populasi untuk dipilih menjadi anggota sampel. Jumlah sampel 143 orang kualifikasi tingkat usia (remaja 13-18 dan dewasa 18-40) dari 580 populasi pada 3 komunitas lari yang ada di Kota Bandung diantaranya: Indorunners 
Bandung, Fakerunners Bandung dan RIOT Bandung (running is our therapy) anggota komunitas lari yang telah mengikuti kegiatan aktivitas fisik.

Pada penelitian ini metode untuk mengukur penggunaan aplikasi olahraga menggunakan pengukuran yang digunakan oleh (Janssen et al., 2017). Kuisioner yang digunakan oleh Janssen et al., (2017) adalah kuisioner dikembangkan untuk mengumpulkan informasi tentang pelari. Kuesioner terdiridari dua bagian: (1) Karakteristik sosio demografi (seperti usia, jenis kelamin, dan tingkat pendidikan); menjalankan karakteristik (seperti frekuensi pelatihan, konteks organisasi, olahraga utama, dan partisipasi acara); dan (2) Karakteristik psikografis (seperti motif dan sikap terhadap berlari). Penggunaan aplikasi (kode biner sebagai 1 ya / 0 tidak); dan penggunaan jam tangan olahraga (kode biner sebagai 1 ya / 0 tidak). Responden diminta untuk mengisi aplikasi mereka dan jam tangan olahraga (didefinisikan sebagai menggunakan satuatau lebih banyak aplikasi yang terkait dengan lari / olahraga menonton dalam dua belas bulan terakhir). Para responden juga diminta untuk memberikan perincian tentang merek dan model spesifik yang mereka gunakan.

Sedangkan untuk instrumen motivasi intrinsik menggunakan pada penelitian ini metode mengukur motivasi intrinsik yaitu competence motivation (Pelletier et al., 1995). Ada enam sub variabel dalam competence motivation yaitu memiliki konsentrasi yang tinggi, penampilan yang lebih baik, self-determinasi, dan kepuasan pribadi. Instrumen penelitian yang diadopsi dari penelitian yang dilakukan oleh Kondric et al., (2013), peneliti menggunakan "Back Translation Methode " dari Esposito (2001) yaitu dengan menerjemahkan PMQ kedalam bahasa Indonesia oleh ahli bilingual, selanjutnya diterjemahkan kembali ke bahasa Inggris oleh ahli bilingual yang berbeda setelah itu diterjemahkan kembali ke bahasa Indonesia untuk dipakai sebagai instrument penelitian. Sehingga penggunaan PMQ yang mengadopsi dari penelitian sebelumnya dapat dilakukan dengan tepat.
Kemudian penilaian perilaku hidup sehat dari Giriwijoyo (2012) yaitu jasmani (aktivitas fisik, nutrisi, cukup istirahat, perilaku atau gaya hidup positif lain untuk kesehatan), rohani (meningkatkan volume dan kualitas kehidupan beragama dan pengendalian atau manaejen stress), dan sosial (interaksi dengan orang lain).

Untuk katagori uraian tentang alternatif jawaban dalam kuesioner. Peneliti menggunakan skala Likert lima poin (mulai dari sama sekali tidak setuju) hingga 5 (sepenuhnya sangat setuju) dengan katagori sebagai: yaitu Sangat Setuju (SS) $=5$, Setuju $(\mathrm{S})=4$, Ragu-ragu $(\mathrm{R})=3$, Tidak Setuju $(\mathrm{TS})$ $=2$, Sangat Tidak Setuju (STS) $=1$. Katagori untuk setiap pertanyaan negatif, yaitu Sangat Setuju $(\mathrm{SS})=1$, Setuju $(\mathrm{S})=2$, Ragu-ragu $(\mathrm{R})=3$, Tidak Setuju (TS) $=4$, Sangat Tidak Setuju $(\mathrm{STS})=5$. Dalam hal ini kuisioner diadaptasi oleh peneliti dan dimodifikasi sesuai dengan kebutuhan peneliti.

Analisis data statistik yang digunakan pada penelitian ini bermaksud untuk mengetahui makna dari sata yang diperoleh dalam rangka memecahkan masalah yang ada pada penelitian ini. Adapun langkah-langkah yang penulis lakukan adalah sebagai berikut: (1) Menyeleksi angket yang terkumpul. Proses ini yntuk memastikan seluruh item butir pertanyaan diisi oleh responden; (2) Memberikan skor pada tiap butir petanyaan yang diseduaikan dengan kriteria penelitian yang ditetapkan; \& (3) Menginput data dari skor tersebut pada program Microsoft Exel. Selanjutnya teknik pengolahan data dalam hal ini mengungkapkan mengenai gambaran data hasil penelitian. Pengolahan dilakukan dengan menggukan menu analyze, description. Explore data pada program SPSS 20. Uji prasyarat statistik meliputi uji normalitas Teknik yang digunakan untuk menguji data menggunakan SPSS 20 dengan uji Kolmogorov-Smirnov. Berikutnya uji hipotesis, uji hipotesis data dilakukan guna mendapatkan kesimpulan dari data yang diperoleh, jenis analisis statistik untuk uji hipotesis dalam rangka mencari kesimpulan penulis menggunakan pengolahan dengan uji korelasi tunggal dan korelasi ganda. 


\section{HASIL DAN PEMBAHASAN}

\subsection{Hasil}

Hipotesis 1: Hubungan antara
Penggunaan Aplikasi dengan Perilaku Hidup

Sehat Pada Komunitas lari Berdasarkan Tingkat Usia.

Tabel 1. Hasil Uji Hubungan Penggunaan Aplikasi dengan Perilaku Hidup Sehat Pada Komunitas Lari Berdasarkan Tingkat Usia

\begin{tabular}{ccccc}
\hline Variabel & $\begin{array}{c}\text { Kualifikasi } \\
\text { Tingkat Usia }\end{array}$ & $\boldsymbol{R}$ & $\boldsymbol{R}$ Square & Sig. \\
\hline $\begin{array}{c}\text { Penggunaan Aplikasi } \\
\text { dengan Perilaku } \\
\text { Hidup Sehat }\end{array}$ & \begin{tabular}{c} 
Semua Level \\
\cline { 2 - 5 }
\end{tabular} & 0,544 & 0,295 & 0,0001 \\
\cline { 2 - 5 } & $13-18$ Tahun & 0.798 & 0,637 & 0,032 \\
\hline
\end{tabular}

Berdasarkan Tabel 1 diketahui bahwa didapat signifikansi sebesar 0,0001 untuk penggunaan aplikasi semua level/kualifikasi. Karena nilai signifikansi lebih kecil dari 0,05 $(0,0001<0,05)$ maka H0 ditolak dengan kata lain H1 diterima (Bambang, 2012). Berarti dapat disimpulkan bahwa terdapat hubungan yang signifikan antara penggunaan aplikasi dengan perilaku hidup sehat semua level/ kualifikasi. Adapun kontribusi penggunaan aplikasi terhadap perilaku hidup sehat semua level/kualifikasi sebesar 29,5\%. Sedangkan diketahui bahwa didapat signifikansi sebesar 0,032 untuk penggunaan aplikasi berdasarkan kualifikasi tingkat usia 13-18 tahun. Karena nilai signifikansi lebih kecil dari $0,05(0,032$ $<0,05)$ maka $\mathrm{H} 0$ ditolak dengan kata lain $\mathrm{H} 1$ diterima.

Berarti dapat disimpulkan bahwa terdapat hubungan yang signifikan antara penggunaan aplikasi dengan perilaku hidup sehat. Adapun kontribusi penggunaan aplikasi terhadap perilaku hidup sehat berdasarkan tingkat usia 13 -18 tahun sebesar $63,7 \%$. Kemudian didapat signifikansi sebesar 0,0001 untuk penggunaan aplikasi berdasarkan kualifikasi tingkat usia $18-40$ tahun. Karena nilai signifikansi lebih kecil dari $0,05(0,0001<0,05)$ maka H0 ditolak dengan kata lain $\mathrm{H} 1$ diterima. Berarti dapat disimpulkan bahwa terdapat hubungan yang signifikan antara penggunaan aplikasi dengan perilaku hidup sehat. Adapun kontribusi penggunaan aplikasi dengan perilaku hidup sehat pada komunitas lari berdasarkan kualifikasi tingkat usia 18 - 40 tahun sebesar $29,7 \%$.

Hipotesis 2: Hubungan antara Motivasi Intrinsik dengan Perilaku Hidup Sehat Pada Komunitas lari Berdasarkan Gender dan Tingkat Usia.

Tabel 2. Hasil Uji Korelasi Motivasi Intrinsik dengan Perilaku Hidup Sehat Pada Komunitas Lari Berdasarkan Tingkat Usia

\begin{tabular}{ccccc}
\hline Variabel & $\begin{array}{c}\text { Kualifikasi } \\
\text { Tingkat Usia }\end{array}$ & $\boldsymbol{R}$ & $\begin{array}{c}\boldsymbol{R} \\
\text { Square }\end{array}$ & Sig. \\
\hline Motivasi Intrinsik & Semua Level & 0,320 & 0,103 & 0,0001 \\
\cline { 2 - 5 } $\begin{array}{c}\text { dengan Perilaku } \\
\text { Hidup Sehat }\end{array}$ & $13-18$ Tahun & 0,548 & 0,300 & 0,203 \\
\cline { 2 - 5 } & $18-40$ Tahun & 0,323 & 0,104 & 0,0001 \\
\hline
\end{tabular}

Berdasarkan Tabel 2 diketahui bahwa didapat signifikansi sebesar 0,0001 untuk penggunaan aplikasi semua level/kualifikasi. Karena nilai signifikansi lebih kecil dari 0,05 $(0,0001<0,05)$ maka H0 ditolak dengan kata lain $\mathrm{H} 1$ diterima. Berarti dapat disimpulkan bahwa terdapat hubungan yang signifikan antara penggunaan aplikasi dengan perilaku hidup sehat semua level/kualifikasi. Adapun kontribusi penggunaan aplikasi terhadap perilaku hidup sehat semua level/kualifikasi sebesar 10,3\%. Selanjutnya diketahui bahwa didapat signifikansi sebesar 0,203 untuk penggunaan aplikasi berdasarkan kualifikasi tingkat usia 13 - 18 tahun. Karena nilai signifikansi lebih besar dari 0,05 (0,203 > $0,05)$ maka maka H0 diterima. Berarti dapat disimpulkan bahwa tidak terdapat hubungan 
yang signifikan antara penggunaan aplikasi dengan perilaku hidup sehat. Adapun kontribusi penggunaan aplikasi terhadap perilaku hidup sehat berdasarkan tingkat usia 13 -18 tahun sebesar 30,0\%. Kemudian didapat signifikansi sebesar 0,0001 untuk penggunaan aplikasi berdasarkan kualifikasi tingkat usia $18-40$ tahun. Karena nilai signifikansi lebih kecil dari 0,05 $(0,0001<$ $0,05)$ maka H0 ditolak dengan kata lain H1 diterima. Berarti dapat disimpulkan bahwa terdapat hubungan yang signifikan antara penggunaan aplikasi dengan perilaku hidup sehat. Adapun kontribusi penggunaan aplikasi dengan perilaku hidup sehat pada komunitas lari berdasarkan kualifikasi tingkat usia 18 40 tahun sebesar $14,0 \%$.

Hipotesis 3: Hubungan antara Penggunaan Aplikasi dan Motivasi Intrinsik dengan Perilaku Hidup Sehat Pada Komunitas lari Berdasarkan Gender dan Tingkat Usia.

Tabel 3. Hasil Uji Hubungan antara Penggunaan Aplikasi dan Motivasi Intrinsik dengan Perilaku Hidup Sehat Pada Komunitas Lari Berdasarkan Tingkat Usia

\begin{tabular}{ccccc}
\hline $\begin{array}{c}\text { Kualifikasi } \\
\text { Tingkat usia }\end{array}$ & $\boldsymbol{R}$ & $\begin{array}{c}\boldsymbol{R} \\
\text { Square }\end{array}$ & Persamaan garis & Sig. \\
\hline Semua tingkat usia & 0,559 & 0.313 & $\mathrm{Y}=52,115+1,264 \mathrm{X} 1+0,296 \mathrm{X} 2$ & 0,0001 \\
\hline $13-18$ Tahun & 0,852 & 0,727 & $\mathrm{Y}=-12,027+1,695 \mathrm{X} 1+0,712 \mathrm{X} 2$ & 0,075 \\
\hline $18-40$ Tahun & 0,561 & 0,313 & $\mathrm{Y}=54,150+1,246 \mathrm{X} 1+0,279 \mathrm{X} 2$ & 0,0001 \\
\hline
\end{tabular}

Berdasarkan Tabel 3 setelah dilakukan analisis, pada komunitas lari semua level / kualifikasi ternyata variabel independen yang masuk model adalah Pengguna Aplikasi dan Motivasi Intrinsik. Dari hasil multivariate bisa kita lihat bahwa variabel independen yang berhubungan signifikan dengan perilaku hidup sehat semua level/kualifikasi adalah pengguna aplikasi dan motivasi intrinsik. Pada model summery terlihat koefisien determinasi $(R$ Square) menunjukkan nilai 0.313 artinya bahwa model regresi yang diperoleh dapat menjelaskan $55,9 \%$ variasi variabel dependen perilaku hidup sehat, atau dengan kata lain kedua variabel independen tersebut dapat menjelaskan variasi variabel perilaku hidup sehat sebesar 55,9\%. Kemudian pada kotak anova kita lihat nilai signifikansi 0,0001 berarti pada alpha 5\% kita dapat menyatakan bahwa model regresi cocok dengan data yang ada atau dapat diartikan kedua variabel tersebut secara signifikan dapat untuk memprediksi variabel perilaku hidup sehat semua level/kualifikasi.

Pada kotak koefisien kita dapat memperoleh persamaan garisnya pada kolom B di atas, kita dapat mengetahui koefisien regresi masing-masing variabel. Dari hasil di atas, persamaan regresi yang diperoleh adalah:

$$
\mathrm{Y}=52,115+1,264 \mathrm{X} 1+0,296 \mathrm{X} 2
$$

Dengan model persamaan ini, kita dapat memperkirakan perilaku hidup sehat semua level/kualifikasi dengan menggunakan variabel pengguna aplikasi dan motivasi intrinsik. Adapun arti koefisien B untuk masing-masing variabel adalah sebagai berikut:

a. Setiap peningkatan 1 poin X1 (pengguna aplikasi lari), meningkatkan sebesar 1,264 pada perilaku hidup sehat komunitas lari.

b. Setiap peningkatan 1 poin X2 (motivasi intrinsik), menurunkan sebesar 0,296 pada perilaku hidup sehat komunitas lari.

Pada kolom B dapat digunakan untuk mengetahui variabel mana yang paling besar pengaruhnya dalam menentukan variabel dependen. Semakin besar nilai B semakin besar pengaruhnya terhadap variabel dependen. Dari hasil nilai koefisien B ternyata variabel X1 (pengguna aplikasi) mempunyai nilai paling besar $(1,264)$. Dengan demikian dapat disimpulkan bahwa variabel X1 (pengguna aplikasi) yang paling besar konstribusinya terhadap perilaku hidup sehat semua level/kualifikasi.

Berdasarkan Tabel 3 setelah dilakukan 
analisis, pada komunitas lari kualifikasi tingkat usia 13-18 tahun ternyata variabel independen yang masuk model adalah pengguna aplikasi dan motivasi intrinsik. Dari hasil multivariate nilai signifikansi sebesar 0,075 hal tersebut menunjukkan bahwa tidak ada hubungan yang signifikan antara pengguna aplikasi motivasi intrinsik dengan perilaku hidup sehat kualifikasi tingkat usia 13-18 tahun pada komunitas lari. Berarti pada alpha 5\% kita dapat menyatakan bahwa kedua variabel tersebut, tidak dapat memprediksi variabel perilaku hidup sehat kualifikasi tingkat usia 13-18 tahun. Sedangkan kualifikasi tingkat usia 18-40 tahun ternyata variabel independen yang masuk model adalah pengguna aplikasi dan motivasi intrsinsik. Dari hasil multivariate bisa kita lihat bahwa variabel independen yang berhubungan signifikan dengan perilaku hidup sehat kualifikasi tingkat usia 18-40 tahun adalah pengguna aplikasi dan motivasi intrinsik. Pada model summery terlihat koefisien determinasi $(R$ Square) menunjukkan nilai 0,313 artinya bahwa model regresi yang diperoleh dapat menjelaskan $56,1 \%$ variasi variabel dependen perilaku hidup sehat, atau dengan kata lain kedua variabel independen tersebut dapat menjelaskan variasi variabel perilaku hidup sehat sebesar 56,1\%. Kemudian pada kotak anova kita lihat nilai signifikansi 0,0001 berarti pada alpha 5\% kita dapat menyatakan bahwa model regresi cocok dengan data yang ada atau dapat diartikan kedua variabel tersebut secara signifikan dapat untuk memprediksi variabel perilaku hidup sehat kualifikasi tingkat usia 18-40 tahun.

Pada kotak koefisien kita dapat memperoleh persamaan garisnya pada kolom B di atas, kita dapat mengetahui koefisien regresi masing-masing variabel. Dari hasil di atas, persamaan regresi yang diperoleh adalah:

$$
\mathrm{Y}=54,150+1,246 \mathrm{X} 1+0,279 \mathrm{X} 2
$$

Dengan model persamaan ini, kita dapat memperkirakan perilaku hidup sehat kualifikasi kualifikasi tingkat usia 18-40 tahun dengan menggunakan variabel pengguna aplikasi dan motivasi intrinsik. Adapun arti koefisien B untuk masing-masing variabel adalah sebagai berikut:

a. Setiap peningkatan 1 poin $\mathrm{X} 1$ (pengguna aplikasi lari), meningkatkan sebesar 1,246 pada perilaku hidup sehat komunitas lari.

b. Setiap peningkatan 1 poin X2 (motivasi intrinsik), menurunkan sebesar 0,279 pada perilaku hidup sehat komunitas lari.

Pada kolom B dapat digunakan untuk mengetahui variabel mana yang paling besar pengaruhnya dalam menentukan variabel dependen. Semakin besar nilai B semakin besar pengaruhnya terhadap variabel dependen. Dari hasil nilai koefisien B ternyata variabel X1 (pengguna aplikasi) mempunyai nilai paling besar $(1,246)$. Dengan demikian dapat disimpulkan bahwa variabel X1 (pengguna aplikasi) yang paling besar konstribusinya terhadap perilaku hidup sehat kualifikasi tingkat usia 18-40 tahun.

\subsection{Pembahasan}

Dari hasil perhitungan korelasional Spearman didapatkan hasil yang menyatakan bahwa pengguna aplikasi lari memiliki hubungan yang sedang dan signifikan dengan perilaku hidup sehat dalam kominitas lari di Bandung pada semua level/kualifikasi. Seperti yang dinyatakan oleh Naimark et al., (2015) penelitian menunjukkan bahwa penggunaan aplikasi berbasis web pada indikator gaya hidup menurunkan berat badan dan peningkatan aktivitas fisik. Bahkan, pengguna aplikasi memberikan peluang lebih tinggi untuk mempertahankan gaya hidup yang sehat. Singkatnya, bahwa efek penggunaan aplikasi pada perubahan aktivitas fisik dan kesehatan dalam menjalankan rekreasi penggunaan aplikasi tinggi dan muncul beberapa aplikasi telah dikembangkan untuk membantu individu dalam latihan lari mereka. Hal itu menunjukkan bahwa faktor dari penggunaan aplikasi dapat menjadi bagian yang berpengaruh dalam olahraga.

Dalam konteks olahraga lari Vos et al., (2016) yaitu dia membuat aplikasi lari yaitu inspirun, sistem cerdas untuk pelari 
rekreasi adalah kombinasi dari pelatihan yang dipersonalisasi pendekatan dengan penyesuaian otomatis skema pelatihan berdasarkan biofeedback dan hasil-data GPS, bahwa aplikasi tersebut memandu mereka berlari dengan intensitas yang lebih rendah yaitu pencegahan cedera. Sistem cerdas seperti aplikasi smartphone dapat memiliki peran kunci dalam merangsang aktivitas fisik dan partisipasi olahraga berkelanjutan. Hal itu menunjukkan bahwa penggunaan aplikasi yang mendukung dalam melakukan aktivitas fisik yaitu salah satu dengan melakukan aktivitas lari yang menjadi pengaruh dan berperan penting dalam tercapainya perilaku hidup sehat. Hal itu menunjukkan pentingnya penggunaan aplikasi bagi seorang pelaku olahraga dalam melakukan kegiatannya. Begitu pun bagi setiap golongan masyarakat seorang pelari, pesepeda, perenang, dan yang akan melakukan aktivitas kesehariannya seperti berjalan. Penggunaan aplikasi merupakan pendukung untuk memantau aktivitas yang dilakukan sebagai feedback bagi penggunanya. Perangkat elektronik juga dapat memainkan peran dalam mendukung dan memantau kelompok pelari yang tidak terorganisir, yaitu yang tidak memiliki pelatihan dan pembinaan profesional.

Kemudian pada penelitian ini, peneliti juga mengelolah data untuk melihat hubungan antar variabel dengan memisahkan sampel komunitas lari sesuai dengan level/ kualifikasi berdasarkan tingkat usia yaitu 13-18 tahun, 18-40 tahun, dan 40-60 tahun. Untuk kualifikasi tingkat usia 13-18 tahun didapatkan hasil yang menyatakan bahwa penggunan aplikasi lari mempunyai hubungan yang kuat dan signifikan dengan perilaku hidup sehat kualifikasi tingkat usia 13-18 tahun dalam melakukan aktivitas larinya. Dan untuk komunitas lari tingkat usia 1840 tahun didapatkan hasil yang menyatakan bahwa penggunaan aplikasi lari mempunyai hubungan yang sedang dan signifikan dengan perilaku hidup sehat kualifikasi tingkat usia 18-40 tahun dalam melakukan aktivitas lari.

Dari pemaparan sesuai dengan tingkat kualifikasi komunitas lari di atas, hasilnya dapat disimpulkan bahwa semakin tinggi level kualifikasi komunitas lari, maka semakin sering menggunakan aplikasi yang dimiliki. Pada kualifikasi komunitas lari kualifikasi tingkat usia 13-18 tahun, merupakan tingkatan pertama sebagai seorang termuda yang mengikuti kamunitas lari. Tentunya hal itu akan menimbulkan banyak pertanyaan dalam diri mereka tersebut, perasaan takut, gelisah, atau membayangkan kejadian yang tidak diinginkan, atau tidak akan diterima dalam lingkungan yang baru yang mereka ikuti.

Pendapat Recio-Rodriguez (2014) Teknologi ini telah memungkinkan aplikasi smartphone untuk memantau parameter biologis, diabetes, rehabilitasi jantung pada orang tua, dan aktivitas fisik. King et al., (2010) Aplikasi juga tampaknya bermanfaat untuk mengurangi rata-rata jumlah menit harian yang dihabiskan oleh peserta yang duduk di depan televisi, perilaku menetap yang sangat lazim di antara individu dalam kelompok usia paruh baya dan lebih tua. Berbeda dengan pendapat menurut Borgers et al., (2016) mengatakan bahwa kalitas berlari yang menarik adalah yang berfokus pada kesehatan, tidak memaksakan batasan usia, tidak memerlukan infrastruktur khusus, dan bisa dipraktikkan secara sendiri pada waktu dan tempat.

Fox \& Duggan (2012) yang mangatakan bahwa di Amerika smartphone memungkinkan penggunaan aplikasi perangkat lunak seluler untuk membantu orang melacak atau mengelola kesehatan mereka. Sekitar 19\% pemilik smartphone memiliki setidaknya satu aplikasi kesehatan di ponsel mereka. Aplikasi olahraga, diet, dan berat badan adalah jenis yang paling populer. Dari penjelasan tersebut dapat disimpulkan bahwa banyak orang yang menggunakan aplikasi kesehatan yaitu salah satunya adalah aplikasi untuk olahraga.

Dalam hal ini, telah muncul beberapa aplikasi telah dikembangkan untuk membantu membantu individu dalam latihan lari mereka. Chatton \& Kayser (2013); Lane et al., (2010) penelitian telah menunjukkan bahwa rekreasi berjalan atau partisipasi dalam menjalankan acara massal juga bisa menjadi potensi yang 
mempromosikan aktivitas kesehatan dan aktivitas fisik. Selain itu, dalam persiapan untuk 5 dan $10 \mathrm{~km}$ menjalankan peserta meningkatkan aktivitas fisik (Stevinson \& Hickson, 2014; Lane et al., 2010). Sebagian besar peserta berlatih dalam persiapan untuk acara berlari, beberapa dari mereka berolahraga secara individu dan sebagian lagi mereka dalam grup yang sedang berjalan (Celie et al., 2010).

Sebaliknya, baru-baru ini penelitian oleh Hendry et al., (2014) menemukan itu kegiatan latihan dan bermain tidak terkait dengan tingkat masa depan motivasi intrinsik atau otonom dalam sampel pemain sepak bola pemuda elit. Deci \& Ryan (2002) berpendapat bahwa memotivasi intrinsik behaviors (misalnya permainan yang disengaja) memiliki efek positif dari waktu ke waktu pada motivasi ditentukan sendiri individu berdasarkan self-determination theory (SDT).

Keyakinan dari seorang akan memengaruhi motivasi intrinsik individu yang membantu mempertahankan perilaku hidup sehat untuk menjadwal olahraga disetiap harinya. Seperti dalam penelitian De Bruin et al., (2007) menunjukkan bahwa pengukuran terkait langsung yakin akan motivasi spesifik dalam olahraga catur (yaitu "Saya ingin menjadi catur grandmaster") lebih kuat terkait dengan praktik yang disengaja daripada ukuran yang lebih jauh dari motivasi berprestasi. Sama halnya dengan seorang yang ingin menerapkan perilaku hidup sehat (yaitu "saya ingin menerapkan olahraga lari setiap harinya) bagi individu yang termotivasi intrinsik akan menerapkan latihan tersebut. Pelaku olahraga yang ingin selalu menerapkan kegiatan olahraga diantara berlari, berenang, atau olahraga lainnya.

Penelitian King et al., (2013) tentang pemanfaatan ponsel dari berbabai motif untuk mempromosikan aktivitas harian dan mengurangi sikap sedentary. Hasil penelitiannya menujukkan bahwa Lebih dari dua pertiga peserta $(69 \%)$ melaporkan bahwa aplikasi tersebut memotivasi mereka untuk lebih aktif secara fisik dan kurang duduk (74\%), dan mayoritas peserta melaporkan bahwa aplikasi membantu mereka ingat untuk berolahraga secara teratur (71\%). Hasil ini sesuai dengan pendapat dengan Teixeira et al., (2012) bahwa motivasi adalah faktor penting dalam mendukung olahraga berkelanjutan, yang pada gilirannya dikaitkan dengan hasil kesehatan yang penting. Orang yang sudah terbiasa melakukan olahraga cendrung akan merasa tertekan apabila tidak melakukan olahraga dalam sehari.

Kesadaran akan pentingnya perilaku hidup sehat harus dibangun dari diri sendiri. Hal ini sependapat dengan Edmunds et al., (2008) mempertahankan gaya hidup aktif secara fisik mungkin membutuhkan upaya tingkat tinggi, sering kali untuk hal-hal duniawi atau kegiatan berulang, regulasi dengan identifikasi dengan hasil mungkin lebih penting daripada berolahraga untuk bersenang-senang dan kegembiraan, atau untuk menantang diri sendiri. Keyakinan dari seorang akan memengaruhi motivasi intrinsik individu yang membantu mempertahankan perilaku hidup sehat untuk menjadwal olahraga disetiap harinya.

\section{KESIMPULAN}

Singkatnya, penelitian ini menemukan bahwa penggunaan aplikasi mempunyai hubungan dengan perilaku hidup sehat dalam melakukan aktivitas lari. Penggunaan aplikasi menjadi salah satu aspek yang penting tidak hanya untuk seorang pelari, aplikasi yang berkaitan dengan kesehatan bisa dipakai oleh berbagai kalangan masyarakat. Pada zaman sekarang karena dengan kemajuan teknologi kurangnya pembekalan yang diberikan mengenai aspek kesehatan yang harus dimiliki oleh setiap individu. Secara umum temuan ini mendukung penelitian yang dilakukan oleh Dallinga et al., (2015), penggunaan aplikasi dapat membantu pelari untuk meningkatkan motivasi, meningkatkan tingkat aktivitas dan menetapkan tujuan selama persiapan untuk acara lari. Mungkin penggunaan aplikasi bisa membantu pelari untuk meningkatkan aktivitas fisik berjalan dan untuk hidup lebih sehat. Hasil ini menunjukkan bahwa penggunaan aplikasi seluler memiliki peran yang menguntungkan dalam persiapan acara, 
berlari karena mempromosikan kesehatan dan aktivitas fisik. Pendapat Dalinga et al., (2015) menunjukkan bahwa penggunaan aplikasi seluler memiliki peran yang menguntungkan dalam persiapan acara berlari, karena mempromosikan kesehatan dan aktivitas fisik. Hal ini sesuai dengan penelitian Glynn et al., (2014) yang menyatakan bahwa bahwa olahraga dan aktivitas fisik - terkait dengan perangkat pemantauan memiliki potensi untuk berkontribusi pada gaya hidup yang lebih sehat dan dapat menjadi penting pendorong perubahan perilaku menuju gaya hidup sehat.

Dari penjelasan tersebut dapat disimpulkan bahwa penggunaan aplikasi mempunyai pengaruh yaitu sebagai pendukung untuk perubahan menuju perilaku hidup sehat dalam menerapkan aktivitas fisik. Selain itu motivasi intrinsik mempunyai hubungan dengan perilaku hidup sehat dalam melakukana aktivitas lari, ketika seorang pelari termotivasi secara intrinsik yaitu atas kemauan dari dalam diri sendiri dapat mempertahankan setiap peningkatan jangka panjang dalam aktivitas fisik. Seperti dalam penelitian De Bruin et al., (2007) menunjukkan bahwa pengukuran terkait langsung yakin akan motivasi spesifik dalam olahraga catur (yaitu "Saya ingin menjadi catur grandmaster") lebih kuat terkait dengan praktik yang disengaja daripada ukuran yang lebih jauh dari motivasi berprestasi. Sama halnya dengan seorang yang ingin menerapkan perilaku hidup sehat (yaitu "saya ingin menerapkan olahraga lari setiap harinya) bagi individu yang termotivasi intrinsik akan menerapkan latihan tersebut. Pelaku olahraga yang ingin selalu menerapkan kegiatan olahraga diantara berlari, berenang, atau olahraga lainnya. Motivasi intrinsik terjadi ketika seorang individu berpartisipasi dalam suatu aktivitas untuk kesenangan atau kenikmatan yang melekat dalam aktivitas itu sendiri.

Penggunaan aplikasidan motivasi intrinsik mempunyai hubungan dengan perilaku hidup sehat dalam melakukan aktivitas lari. Kedua aspek tersebut berperan penting bagi seorang pelaku olahraga. Ketika seorang pelaku olahraga sudah mempunyai aplikasi kesehatan dan/ kebugaran, maka akan mendorong dirinya untuk terus menerapkan perilau hidup sehat ataupun meningkatkat aktivitas fisik.

\section{DAFTAR RUJUKAN}

Bambang, R. (2012). Dasar-dasar Pembelanjaan. Edisi 4. Yogyakarta: BPFE.

Bhattacharyya, R. (2015). Addiction to Modern Gadgets and Technologies across Generations. Eastern Journal of Psychiatry, 18(2), 27-37.

Bisnis.com. (2018). Pengguna Perangkat Mobile di Indonesia Semakin Tinggi ini. [Online]. Diakses dari: http:// Industri.bisnis.com/read/20180201/101/733037/ pengguna-peraangkat-mobile-di-indonesia-semakintinggi-ini-datanya.

Celie, F., Faes, M., Hopman, M., Stalenhoef, A. F., \& Rikkert, M. G. O. (2010). Running on age in a 15-km road run: minor influence of age on performance. Eur Rev Aging Phys Act, 7(1), 43-7.

Chatton, A., \& Kayser, B. E. (2013). Self-reported health, physical activity and socioeconomic status of middleaged and elderly participants to a popular road running race in Switzerland: better off than the general population?. Swiss Med Wkly, 143:1-9.

Cote, J., Murphy-Mills, J., \& Abernethy, B. (2012). The development of skill in sport. In A. M. Williams, \& N. J. Hodges (Eds.), Skill acquisition in sport (2nd ed.). London: Routledge.

Dallinga, J. M., Mennes, M., Alpay, L., Bijwaard, H., \& Faille-Deutekom M. (2015). App use, physical activity and healthy lifestyle: a cross sectional study. BMC Public Health, 15(1):833.

De Bruin, A. B., Rikers, M. J., \& Schmidt, H. G. (2007). The influence of achievement motivation and chessspecific motivation on deliberate practice. Journal of Sport \& Exercise Psychology, 29, 561-583.

Deci, E. L., \& Ryan, R. M. (2000). The "What" and "Why" of Goal Pursuits: Human Needs and the SelfDetermination of Behavior. Psychological Inquiry, 11(4), 227-268.

Edmunds, J., Ntoumanis, N., \& Duda, J. L. (2008). Testing a self-determination theory based teaching style in the exercise domain. European Journal of Social Psychology, 38, 375-388. 
Esposito, N. (2001). From Meaning to Meaning: The Influence of Translation Techniques on Non-English Focus Group Research. Qualitative Health Research, 11(4), 568-579.

Fanning, J., Mullen, S. P., McAuley, E. (2012). Increasing physical activity with mobile devices: a meta-analysis. $J$ Med Internet Res, 14(6), 161.

Fox, S., \& Duggan, M. (2012). Half of smartphone owners use their devices to get health information and one-fifth of smartphone owners have health apps. [Online]. Diakses dari: http://www.pewinternet.org/ /media// Files/Reports/2012/PIP_MobileHealth2012_FINAL.pdf.

Glynn, L. G., Hayes, P. S., Casey, M., Glynn, F., Alvarez-Iglesias, A., Newell, J., OLaighin, G., Heaney, D., O’Donnell, M., Murphy A. W. (2014). Effectiveness of a smartphone application to promote physical activity in primary care: The SMART MOVE randomised controlled trial. Br J Gen Pract, 64(624), 384-91.

Giriwijoyo, H. Y. S., \& Sidik, D. Z. (2012). Ilmu Faal Olahra. Bandung: FPOK UPI

Hendry, D. T., Crocker, P. R. E., \& Hodges, N. J. (2014). Practice and play as determinants of self-determined motivation in youth soccer players. Journal of Sports Sciences, 32.

Janssen, M., Scheerder, J., Thibaut, E., Brombacher, A., \& Vos, S. (2017). Who uses running apps and sports watches? Determinants and consumer profiles of event runners' usage of running-related smartphone applications and sports watches. PLoS ONE, 12(7).

Borgers, J., Vanreusel, B., Vos, S., Forsberg, P., \& Scheerder, J. (2016). Do light sport facilities foster sports participation? A case study on the use of bark running tracks. International journal of sport policy and politics, 8(2), 287-304.

King, A. C., Goldberg, J. H., Salmon, J., Owen, N., Dunstan, D., Weber, D., Doyle, C., \& Robinson, T. N. (2010). Identifying subgroups of U.S. adults at risk for prolonged television viewing to inform program development. Am J Prev Med, 38, 17-26.

King, A. C., Hekler, E. B., Grieco, L. A., Winter, S. J., Sheats, J. L., Buman, M. P., Naberjee, B., Robinson, T. N., \& Cirimele, J. (2013). Harnessing Different Motivational Frames via Mobile Phones to Promote Daily Physical Activity and Reduce Sedentary Behavior in Aging Adults. PLoS ONE, 8(4).

Pelletier, D. L., Frongillo., Edward, A., Schroeder, D. G., \& Habicht, J. P. (1995). The Effects of malnutrition on child mortality in developing countries / D. L. Pelletier. Bulletin of the World Health Organization, Vol 73(4), Hal: 443-448.

Kominfo.go.id. (2014) Riset Kominfo dan UNICEF Mengenai Perilaku Anak dan Remaja dalam Menggunakan Internet. [Online]. Diakses dari: https://kominfo.go.id/index.php/content/detail/3834/Siaran+Pers+No.+7PIH-KOMINFO-22014+tentang+Riset+Kominfo+dan+UNICEF+Mengenai+Perilaku+Anak+dan+Rem aja+Dalam+Menggunakan+Internet+/0/siaran_pers.

Kondric, M., Sindik, J., Furjan-Mandic, G., \& Schiefler, B. (2013). Participation Motivation and Student's Physical Activity among Sport Students in Three Countries. Journal of Sport Science and Medicine, 12(1), 10-18.

Kranz, A. L., Jiao, C. Y., Winterkorn, L. H., Albritton, S. E., Kramer, M., \& Ercan, S. (2013). Genome-wide Analysis of Condensin Binding in Caenorhabditis Elegans. Genome Biology, 14, 1-15.

Lane, A., Murphy, N., Bauman, A., \& Chey, T. (2010). Randomized controlled trial to increase physical activity among insufficiently active women following their participation in a mass event. Health Educ J, 69(3), 287-96.

Lee IM. (2003). Physical activity and cancer prevention — Data from epidemiologic studies. Med Sci Sports Exerc, 35(11), 1823-1827.

Simuforosa, M. (2013). The impact of modern technology on the educational attainment of adolescents. International Journal of Education and Research, 1(9).

Middelweerd, A., Mollee, J. S., van der W. C., Brug, J. \& te Velde, S. J. (2014). Apps to Promote Physical Activity among Adults: A Review and Content Analysis. International Journal of Behavioral Nutrition and Physical Activity, 11, 97.

Naimark, S. J., Madar, Z., \& Shahar, R. D. (2015). The Impact of a Web-Based App (eBalance) in Promoting Healthy Lifestyles: Randomized Controlled Trial. J Med Internet, 17(3), 56.

Rahmat, N. N., Munawir, A., \& Bukhori, S. (2017). Duration of Gadget Usage Affects Eye Fatigue in Students Aged 16-18 Years. Humanistic Network for Science and Technology, 1(4), 335-340.

Recio-Rodriguez, J. I., Martin-Cantera, C., Gonzalez-Viejo, N., Gómez-Arranz, A., Arietaleanizbeascoa, M. S., Schmolling-Guinovart, Y., Maderuelo-Fernandez, J. A., Pérez-Arechaederra, D., Rodriguez-Sanchez, E., Gómez-Marcos, M., García-Ortiz, L. (2014). Effectiveness of a smartphone application for improving healthy lifestyles, a randomized clinical trial (EVIDENT II): study protocol. BMC Public Health, 14:254. 
Smart, N., \& Marwick, T. H. (2004) Exercise training for patients with heart failure: a systematic review of factors that improve mortality and morbidity. Am J Med; 116(10): 693-706.

Stevinson, C., \& Hickson, M. (2014). Exploring the public health potential of a mass community participation event. J Public Health (Oxf), 36(2), 268-74.

Subrahmanyam, K., Kraut, R. E., Patricia, M., Greenfield, P. N., \& Gross, E. F. (2000). The Impact of Home Computer Uses on Children's Activities and Development. Future Chile, 10: 123-144

Taylor, R. S., Brown, A., Ebrahim, S., Jolliffe, J., Noorani, H., Rees, Karen., Skidmore, B. Stone, J. A., Thompson, D. R., \& Oldridge. (2004). Exercise-Based Rehabilitation for Patients with Coronary Heart Disease: Systematic Review and Meta-analysis of Randomized Controlled Trials.The American Journal of Medicine, 116(10), 682-692.

Teixeira, P. J., Carraça, E. V., Markland, D. A., Silva, M. N., \& Ryan, R. M. (2012). Exercise, physical activity, and self-determination theory: A systematic review [Electronic version]. Journal of Behavioral Nutrition and Physical Activity, 9, 78.

Upadhyay, A., Justin, J. J., \& Priyanka, C. (2014). Impact of Electronic Gadgets. International Journal of Emerging Trends in Science and Technology, 1(9), 1495-1499.

Vos, S., Janssen, M., Goudsmit, J., Bovens, J., \& Lauwerijssen, C. (2015). Creating light and personalised running experiences: an app development study. [Online]. Diakses dari: https://pure.tue.nl/ws/portalfiles/ portal/18929657/easm2EASM_2015_192_714.pdf.

Vos, S., Janssen, M., Goudsmit, J., Lauwerijssen, C., \& Brombacher, A. (2016). From Problem to Solution: A Three-step Approach to Design a Personalized Smartphone Application for Recreational Runners. Procedia Engineering ISEA, 147, 799-805.

World Health Organization. (2009). Global health risks: mortality and burden of disease attributable to selected major risks. Geneva: World Health Organization.

World Health Organization. (2010). Global Recomendations on Physical for Health. Geneva: WHO.

World Health Organization. (2018). Physical Inactivity: A Global Public Health Problem. [Online]. Diakses dari: [http://www.who.int/mediacentre/factsheets /fs385/en/] 